particularly interested in the EEG, an interest which was to serve him well later. He was them appointed senior registrar in psychiatry at St Thomas'. He obtained the DPM (Eng) in 1956 and was elected MRCPsych in 1971 and proceeded to the Fellowship in 1973. In 1958 he gained the MRCP(Lond) and was elected FRCP in 1976.

In 1959 he was appointed consultant in psychiatry (Chiltern Wing) and EEG at Belmont and Sutton General Hospital, a job he was to fill with distinction until he retired, aged 65 , in 1984. Inter alia, he served as Clinical Tutor from 1966 until his retirement, a remarkable record by any standards.

One of West's major achievements was to set up in 1972, together with two other colleagues, a residential course at Surrey University designed for candidates taking the final MRCPsych examination. To celebrate the 20th year of this eminently successful venture, as well as to pay lasting tribute to him, the first 'Eric West Guest Lecture' was given in 1992 by Dr Peter Fenwick. Sadly, West himself was too ill to attend in person and he had to make do with a tape recording of the proceedings.

West initiated several research projects and made many contributions to the literature. These included a chapter, 'Treatment of Epilepsy', in Sargant and Slater's Introduction to Physical Methods of Treatment in Psychiatry, the 4th edition of which he was to edit.

He met his wife, Joy, when they were students. They were married in 1947. Joy studied medicine in Leeds and at the Royal Free Hospital and qualified MB. ChB Leeds (1953), MRCP LRCP (1953). She too specialised in psychiatry, having acquired the DPM (1967) and MRCPsych (1972) and was appointed consultant to St Helier Hospital, Carshalton, Surrey. She predeceased him in 1979.

There were three children of the marriage, two girls, Hilary and Susan and a boy, John. Hilary is a lecturer in veterinary surgery at Liverpool University and John (MD MRCP) is a senior registrar in cardiology at Queen Elizabeth Hospital, Birmingham.

\title{
Miscellany
}

\section{Defeat Depression}

The Defeat Depression Campaign has prepared a video training package Depression: From Recognition to Management, price $\mathbf{£} 30$. Order forms are available from the Campaign Officer at the College.

An audio tape for general practitioners has been prepared to give or lend to patients, and a booklet on the Recognition and Management of Depression in General Practice is available from the Royal College of General Practitioners. Two patient leaflets have also been produced on Depression and Depression in the Elderly and individual copies are available, on receipt of a stamped addressed envelope, from the Campaign Secretariat at the College.

\section{Appeal from Croatia}

In connection with the appeal for medical supplies to be sent to Croatia (Psychiatric Bulletin, May $1993,17,300-301$ ), it has been suggested that anyone interested in doing this should contact: $\mathrm{Mr}$ Nils Rosdahl, Head of Mission, WHO, Zagreb (telephone 0103841535 725; fax 0103841538 005).

\section{New publications}

The Law Commission has published Mentally Incapacitated and Other Vulnerable Adults: Public Law Protection (C.P. No. 130) and it is available from HMSO, price $£ 7.95$.

The Mental Health Foundation has published Guidelines for the Prevention and Treatment of Benzodiazepine Dependence and copies are available from Bridget Moorman at the Mental Health Foundation, 37 Mortimer Street, London W1R 7RJ (telephone $0715800145)$.

\section{Sir Martin Roth}

Sir Martin Roth was awarded a degree of Doctor of Science (Honoris Causa) by the University of Indiana in May 1993 and he was a recipient of the Camillo Golgi Award in Neuroscience awarded by the Italian Academy of Neuroscience in April 1993.

\section{Change of address}

The address of The King's Fund Institute is now 14 Palace Court, London W2 4HT (telephone 071243 8848; fax 0712217911 ). 